\title{
Poultry as an Experimental Animal Model in Medical Research and Pharmaceutical Industry
}

\author{
Farid S Nassar* \\ Department of Animal Production, Cairo University, Egypt
}

Received: February 01, 2018; Published: February 12, 2018

*Corresponding author: Farid S Nassar, Department of Animal Production, Faculty of Agriculture, Cairo University, Giza 12613, Egypt, Tel: (002) 01094477024; Email: Fidsaber_nassar@agr.cu.edu.eg

\begin{abstract}
Poultry has become a great important for producing meat and egg to face increasing in the world population size form year to the next. In recent years, poultry were used as an experimental animal model in medical research and pharmaceutical industry because of its advantages. The current review will indicate the different application of poultry and its products in wide application in biotechnology in medical research and pharmaceutical industry to study and treatment human diseases. Also, some of poultry diseases viruses used for treatment of human diseases. Using of poultry and chick embryos in medical research and pharmaceutical industry will witness great developments according to the latest knowledge in cell and animal transgenesis in the near future.
\end{abstract}

Keywords: Biotechnology; Experimental animal model; Human diseases; Medical research; Poultry

Abbreviations: CAV: Chicken Anemia Virus; IBDV: Infectious Bursal Disease Virus; NAFLD: Nonalcoholic Fatty Liver Disease; WC-As: White Carneau; IBDV: Infectious Bursal Disease Virus; HCV: Hepatitis C Virus; SPF: Specific Pathogen-Free

\section{Introduction}

During the past few years there has been a notable increase in the demand for poultry meat and egg production due to its low cost, good nutritional profile and suitability for further processing. Moreover, current forecasts and projection studies have predicted that the expansion of the poultry market will continue in the future. This growing demand has led to progressive improvements in genetic selection to produce fast-growing birds [1-3] and increase egg production from egg type chicken [4]. On the other hand, in recent years poultry were used not only as experimental animal model in pharmaceutical and medical research but also in in the pharmaceutical industry because of its advantages such as their short breeding time, simple management, and high productivity are of interest for recombinant therapeutic production in their eggs [5]. Also, Chick embryos are a significant historical research model in basic and applied sciences. Poultry eggs and cell lines derived from embryonated eggs have found wide application in industry and biotechnology. Avian derived cell lines are an alternative for virus production because they provide a simple, flexible system that can be controlled for an extended time with the capability for rapid vaccine production during a pandemic [5]. It is also strange to use viruses that infect poultry a pathogen causing economic losses in chickens in the treatment of human disease such as Infectious bursal disease virus (IBDV) [6] and the chicken anemia virus (CAV)
[7]. Also, many human diseases were studded by using poultry such as cancer, nonalcoholic fatty liver disease (NAFLD), Atherosclerosis [8-11]. Recent advances originated by using transgenic approach highlight the use of avians as animal models in the medical research and pharmaceutical industry.

\section{Chicken as an Experimental Animal Model to Study Ath- erosclerosis and Ovarian Cancer}

Atherosclerosis is one of the leading causes of death in human. As a prevalent complication of type II diabetes, the disease is affecting an increasing population in economically developed countries. Understanding the mechanisms underlying specific pathologies and diseases in human depend on animal models that match specific human pathologies. Atherosclerosis is one of the considerable human diseases that depend on models predominately at the earliest stages of the disease. Pigeon is one of several good animal models for atherosclerosis [12-13]. White Carneau (WCAs) pigeons are susceptible to spontaneous atherosclerosis at the celiac bifurcation of the aorta, whereas show Racer (SR-Ar) pigeon is resistant to the development of atherosclerosis under identical diet and housing conditions, and with similar blood cholesterol levels [14].In addition, many research indicated gene expression which may associated with Atherosclerosis disease development, progression, or both [8-14]. 
On the other hand, the reproductive strategy for avian species that produce a sequence of eggs is dependent upon the maintenance of a small cohort of viable, prehierarchal follicles. It is from this cohort that a single follicle is selected on an approximate daily basis to initiate rapid growth and final differentiation before ovulation [15]. Commercial laying hens spontaneously develop ovarian cancer at a high rate, and susceptibility to this disease has been associated with ovulatory events in women. Also, ovulation or events associated with ovulation increases the prevalence of ovarian cancer in hens. In addition, Genetic selection for high productivity in commercial laying hens has generated an efficient and valuable food source as well as an important animal model for human ovarian cancer which is the fifth leading cause of death from all cancers among women and is the leading cause of death from gynecological malignancies $[11,16]$.

\section{Chicken Disease Viruses and Human Diseases}

Infectious bursal disease virus (IBDV) is a highly infectious virus with a bisegmented double-stranded RNA (dsRNA) genome which causes immunosuppression in chickens. Infectious bursal disease virus has been used as a therapeutic agent without any toxicity in clinical trials with patients suffering from acute and chronic hepatitis C virus (HCV) infections[17,18]. Also, IBDV was used as a vector which shows efficient expression when carrying Hepatitis C Virus Epitopes and demonstrates the potential of IBDV as a vector [6]. The chicken anemia virus (CAV) was first described in 1979 in commercially produced chickens [19]. CAV can lead to great economic loss during intensive chicken farming and control of the virus through vaccination is currently standard practice in poultry farm. The chicken anemia virus (CAV) protein apoptin is known to induce tumor cell-specific death when expressed Apoptin has attracted considerable interest due to its ability to mediate cell death selectively in cells that have undergone an oncogenic Table 1: A number of recombinant proteins produced in avian eggs [5].

\begin{tabular}{|c|c|c|}
\hline Protein & Promoter & Yield \\
\hline Interferon $\propto-2 \mathrm{~b}(\mathrm{hIFN})$ & CMV & $200 \mu \mathrm{g}$ \\
\hline Dansyl hapten mAb & OVA & $<3 \mathrm{mg}$ \\
\hline Prostate specific membrane antigen $\mathrm{mAb}$ & OVA & $<3 \mathrm{mg}$ \\
\hline LacZ & OVA, $3 \mathrm{~kb}$ & $16.47 \mathrm{mU} / \mathrm{mL}$ \\
\hline Antiprion single chain Fv fused with the Fc region ( $\mathrm{ScFv}-\mathrm{Fc}$ ) & Chicken $\beta$-actin & $5.6 \mathrm{mg} / \mathrm{mL}$ \\
\hline ScFv-Fc mini antibody & OVA, $2.8 \mathrm{~kb}$ & $15-50 \mu \mathrm{g} / \mathrm{mL}$ \\
\hline Human IFN-1a & OVA, $2.8 \mathrm{~kb}$ & $3.5-426 \mu \mathrm{g} / \mathrm{mL}$ \\
\hline Human parathormone & RSV & $<823 \mathrm{ng} / \mathrm{mL}$ \\
\hline Human granulocyte-colony stimulating factor & CMV & $<2 \mathrm{mg}$ \\
\hline Human erythroprotein & PGK & $<1 \mathrm{mg}$ \\
\hline Human interleukin 1 receptor antagonist (rh IL1RN) & OVA & $88.7-233.8 \mathrm{ng} / \mathrm{mL}$ \\
\hline Human urokinase-type plasminogen activator & Rous sarcoma virus & $17.20 \mathrm{IU} / \mathrm{egg}$ \\
\hline Human extracellular superoxide dismutase (EC-SOD) & OVA & $10-59 \mathrm{ng} / \mathrm{mL}$ \\
\hline Human lysozyme & OVA & $57.66 \pm 4.10 \mu \mathrm{g} / \mathrm{mL}$ \\
\hline Neutrophil defensin 4 (HNP4) & OVA & $1.65-10.18 \mu \mathrm{g} / \mathrm{mL}$ \\
\hline Recombinant human lysozyme (rhYL) & OVA & $57.66 \pm 4.10 \mu \mathrm{g} / \mathrm{mL}$ \\
\hline
\end{tabular}

transformation. Chicken anemia virus (CAV) is a single-stranded circular DNA virus that carries 3 genes, the most studied of which the gene is encoding VP3, also known as apoptin. This protein has been demonstrated to specifically kill transformed cells while leaving normal cells unharmed. In addition, apoptin is a sensor of DNA damage signaling which induces it to migrate to the nucleus during viral replication. Thus, apoptin has very important advantages in therapeutic different types of human cancer $[7,20]$.

\section{Application of Chicken Eggs and Chicks Embryos in Pharmaceutical Industry}

Oxidative stress and DNA damage play critical roles in various diseases and pathological conditions in human. Moreover, cancer is the second leading cause of human mortality at global level, and commercial and scientific sectors show very strong interests in discovering new anticancer agents from natural sources [21]. In recent years, some scientific arguments indicated that certain bioactive peptides and proteins could have several beneficial effects on human health [22]. Egg is an important source for minerals, vitamins, lipids, and proteins which also considered as an excellent source for biologically active substances [23]. For example, egg yolk is containing Phosvitin which is a phosphoglycoprotein present represents about $7 \%$ of yolk proteins [24]. Phosvitin has a high iron-binding capacity, and the best physicochemical conditions for the high iron-binding capacity are pH 6.5 and the ionic strength of $0.15 \mathrm{M}$ [25]. Phosvitin also exhibited a strong antibacterial activity against a broad spectrum of bacteria and has anti-tyrosinase and melanin biosynthesis activities [26]. Moreover, the Phosvitin showed protective effects against the oxidative stress-induced DNA damages in human leukocytes which suggested using Phosvitin as an anticancer agent for humans [27]. In addition, ovotransferrin and its enzyme hydrolysates produced in eggs can be used as natural growth inhibitors of human cancer cell lines [28]. 
Over few decades, specific pathogen-free (SPF) fertilized poultry eggs have been considered permissive hosts for different types of viral strains to produce mammalian vaccines $[29,30]$. However, industrial sector virus production requires a large amount of SPF fertilized eggs [30]. Avian derived cell lines are an alternative for virus production because they provide a simple, pliable system that can be controlled for prolonged time with the ability for rapid vaccine production during a pandemic [31]. In addition, chicken embryo-derived cells, as primary cell substrates, have been evaluated as hosts for viruses that maintain genomic stability after repeated cell passages [31]. In addition, collectively, these numerous benefits make avian eggs one of the best sources for production of recombinant proteins (Table 1) and using avian cell lines for vaccine production (Table 2). Using poultry in industry and research has gain attention in the field of avian transgenesis according to it's the tremendous potentials [32]. Transgenesis in avians allows producing recombinant protein production, such as therapeutic monoclonal antibodies. Moreover, Transgenesis in avians allows for the possibility of recombinant protein production, such as therapeutic monoclonal antibodies [33].

Table 2: Commercialized avian cell lines for vaccine production [5].

\begin{tabular}{|c|c|c|}
\hline Cell line & Cell type & Strain/species \\
\hline AGE1.CR & Retain cells & Muscovy duck \\
\hline AGE1.CR.pIX & Retain cells & Pekcovy duck duck \\
\hline EB66 & Embryonic stem cells & Gallus gallus chicken \\
\hline EB14 & Embryonic stem cells & Pekin duck \\
\hline DEF & Fibroblast cells & Gallus gallus chicken \\
\hline HD-11 & Macrophage-like cells & Gallus gallus chicken \\
\hline DF-1 & Fibroblast cells & Gallus gallus chicken \\
\hline DT95 & Lymphoblast cells & Japanese quail \\
\hline DT40 & Lymphoblast cells & Japanese quail \\
\hline QEF & Fibroblast cells & Japanese quail \\
\hline QM7 & Muscle cells & Japanese quail \\
\hline QT-35 & Muscle cells & Gallus gallus chicken \\
\hline QT-6 & Muscle cells & Virgina quail \\
\hline PBS-12 SF & Embryo-derived cell & Embryo-derived cell \\
\hline QOR2/2E11 & & \\
\hline
\end{tabular}

\section{Conclusion}

Avian species introduced potential advantages for use in medical research and pharmaceutical industry. Recently, tremendous effort has focused on avian disease viruses, avian eggs, and related cell lines for germline modification in order to create an excellence system platform for the production of therapeutic antibodies, vaccine manufacturing, and recombinant proteins. The application of using poultry and chick embryos in medical research and pharmaceutical industry will witness great developments according to the latest knowledge in cell and animal transgenesis in the near future.

\section{References}

1. Wang SZ, Hu XX, Wang ZP, Li XC, Wang QG, et al. (2012) Quantitative trait loci associated with body weight and abdominal fat traits on chicken chromosomes 3, 5 and 7. Gene and Mole Research 11(2): 956-965.

2. Nassar FS, Moghaieb REA, Abdou AM, Stino FKR (2012) Microsatellite markers associated with body and carcass weights in broiler breeders. Afric J of Biotech 11: 3514-3521.

3. Nassar FS (2017) productive performance in local chicken after five generations of crossing and selection for high live body weight. Egypt Poult Sci 37(3): 779-813.

4. Nassar FS, EL-Komy EM, Abdou AM (2017) Ovarian morphology and egg quality traits of Egyptian selected strain for egg production compared with commercial laying strains. Brazil J of Poult Sci 19(4): 683-688.
5. Farzaneh M, Hassani SN, Mozdziak P, Baharvan H (2017) Avian embryos and related cell lines: A convenient platform for recombinant proteins and vaccine production. Biotechnol J 12(5): 1-10.

6. Upadhyay C, Ammayappan A, Patel D, Kovesdi I, Vakharia VN (2011) Recombinant Infectious Bursal Disease Virus Carrying Hepatitis C Virus Epitopes. J Of Viro 85(4): 1408-1414.

7. Kucharski TJ, Ng TF, Sharon DM, Navid-Azarbaijani P, Tavassoli M, et al. (2016) Activation of the Chicken Anemia Virus Apoptin Protein by Chk1/2 Phosphorylation Is Required for Apoptotic Activity and Efficient Viral Replication. J of Viro 90(20): 9433-9445.

8. Anderson JL, Keeley MC, Smith SC, Smith EC, Taylor RL (2014) Rosiglitazone modulates pigeon atherosclerotic lipid accumulation and gene expression in vitro. Poult Sci 93(6): 1368-1374.

9. Anderson JL, Ashwell CM, Smith SC, Shine R, Smith EC, et al. (2013) Atherosclerosis-susceptible and atherosclerosis-resistant pigeon aortic cells express different genes in vivo. Poult Sci 92(10): 2668-2680.

10. Davis JE, Cain J, Small C, DB Hales (2016) Therapeutic effect of flax-based diets on fatty liver in aged laying hens. Poult Sci 95(11): 2624-2632.

11. Johnson PA, Giles JR (2006) Use of genetic strains of chickens in studies of ovarian cancer. Poult Sci 85(2): 246-250.

12. Moghadasian MH, Frohlich JJ, McManus BM (2001) Advances in experimental dyslipidemia and atherosclerosis. Lab Invest 81(9): 11731183.

13. Anderson JL, Smith SC, RL Taylor (2011) Spontaneous atherosclerosis in pigeons: A good model of human disease. Intech p. 25-48. 
14. Clarkson TB, Prichard RW, Netsky MG, Lofland HB (1959) Atherosclerosis in pigeons: Its spontaneous occurrence and resemblance to human atherosclerosis. AMA Arch Pathol 68(2): 143-147.

15. Johnson AL (2015) ovarian follicle selection and granulosa cell differentiation1. Poult Sci 94(4): 781-785.

16. Johnson PA, Stephens CS, Giles JR (2015) the domestic chicken: Causes and consequences of an egg a day. Poult Sci 94(4): 816-820.

17. Bakacs T, Mehrishi JN (2002) Intentional coinfection of patients with HCV infection using avian infection bursal disease virus. Hepatology 36: 255.

18. Csatary LK, Schnabel R, Bakacs T (1999) Successful treatment of decompensates chronic viral hepatitis by bursal disease virus vaccine. Anticancer Res 19(1B): 629-633.

19. Yuasa N, Taniguchi T, Yoshida I (1979) Isolation and some characteristics of an agent inducing anemia in chicks. Avian Dis 23(2): 366-385.

20. Wu F, Liu Y, Li J, Hou L, Fuxi Lei F, et al. (2017) Human serum albumin mediated apoptin delivery suppresses breast cancer cell growth in vitro and in vivo. Onco Lett 13(2): 579-586.

21. Fouche G, Cragg GM, Pillay P, Kolesnikova N, Maharaj VJ, et al. (2008) In vitro anticancer screening of South African plants. J Ethnopharmacol 119(3): 455-461.

22. Möller NP, Scholz-Ahrens KE, Roos N, Schrezenmeir J (2008) Bioactive peptides and proteins from foods: Indication for health effects. Eur J Nutr 47(4): 171-182.

23. Mine Y (2007) Egg protein and peptides in human health-chemistry, bioactivity and production. Curr Pharm Des 13(9): 875-884.

24. Abe Y, Itoh T, Adachi S (1982) Fractionation and characterization of hens egg yolk phosvitin. J Food Sci 47(6): 1903-1907.

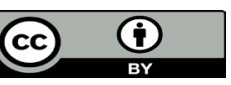

This work is licensed under Creative Commons Attribution 4.0 License

Submission Link: http://biomedres.us/submit-manuscript.php
25. Castellani O, Guérin-Dubiard C, David-Briand E, Anton M (2004) Influence of physicochemical conditions and technological treatments on the iron binding capacity of egg yolk phosvitin. Food Chem 85(4): 569-577.

26. Jung S, Kim DH, Son JH, Nam K, Ahn DU, et al. (2012) The functional property of egg yolk phosvitin as a melanogenesis inhibitor. Food Chem 135(3): 993-998.

27. Moon SH, Lee JH, Lee M, Park E, Ahn DU, et al. (2014) Cytotoxic and antigenotoxic activities of phosvitin from egg yolk. Poult Sci 93(8): 2103-2107.

28. Moon SH, Lee JH, Lee YJ, Chang KH, Paik JY, et al. (2013) Screening for cytotoxic activity of ovotransferrin and its enzyme hydrolysates. Poult Sci 92(2): 424-434.

29. Goodpasture EW, Woodruff AM, Buddingh G (1931) the cultivation of vaccine and other viruses in the chorioallantoic membrane of chick embryos. Science 74: 371-372.

30. Kraus B, Von Fircks S, Feigl S, Koch SM, Fleischanderl D, et al. (2011) Avian cell line-Technology for large scale vaccine production. BMC Proc 5(8): $1-3$

31. Aubrit F, Perugi F, Léon A, Guéhenneux F, Champion-Arnaud P, et al. (2015) Cell substrates for the production of viral vaccines. Vaccine 33(44): 5905-5912.

32. Han JY, Lee HC, Park TS (2015) Germline-competent stem cell in avian species and its application. Asian J. Androl 17(3): 421-426.

33. Houdebine LM (2009) Production of pharmaceutical proteins by transgenic animals. Comp Immunol Microbiol Infect Dis 32(2): 107-121.

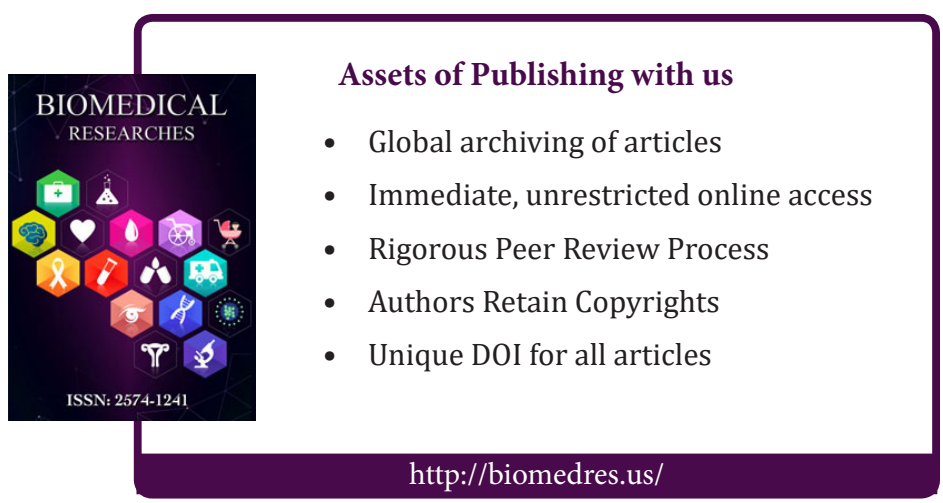

